Boletín de la Sociedad Geológica Mexicana

VOLUMEN 62, NÚM. 2, 2010, P. 207-211

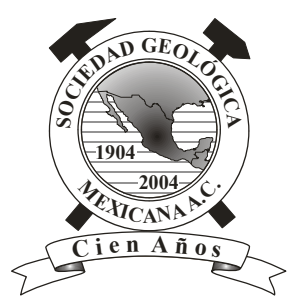

\title{
Additions to Albian (Cretaceous) Crustacea from Iran
}

\author{
Mehdi Yazdi ${ }^{1}$, Ali Bahrami ${ }^{1}$ and Francisco J. Vega ${ }^{2, *}$ \\ ${ }^{1}$ Department of Geology, Faculty of Science, University of Isfahan, 81746, Iran. \\ ${ }^{2}$ Instituto de Geología, UNAM, Ciudad Universitaria, Coyoacán, México, DF 04510, México. \\ *vegver@servidor.unam.mx
}

\begin{abstract}
Two species of decapod crustaceans are described from upper Albian sediments of Central Iran. The small mecochirid lobster Huhatanka iranica n. sp. represents the second species of this genus, previously known from the Albian of Kansas, USA. Callianassa sensu lato is reported as an associated crustacean.
\end{abstract}

Keywords: Crustacea, Mecochiridae, Huhatanka, Albian, Iran.

Resumen

Dos especies de crustáceos son descritos de sedimentos del Albiano superior de Irán central. La pequeña langosta mecoquírida

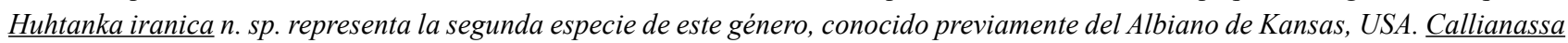
sensu lato es reportada como un crustáceo asociado.

Palabras clave: Crustacea, Mecochiridae, Huhatanka, Albiano, Irán.

\section{Introduction}

Cretaceous decapod crustaceans from Iran are relatively scarce and have been reported just recently: Feldmann et al. (2007), Yazdi et al. (2009), McCobb and Hairapetian (2009). The present contribution reports the fourth and fifth species from upper Albian deposits of Central Iran.

The study area is located approximately in the middle of Central Iran (Figure 1.1, 1.3). Late Silurian to Early Devonian shallow water deposits are the oldest stratigraphic outcrops in this region (Adhamian, 2003; Rahmati, 2009). Due to the Hercynian erosional-epirogenical movement phase in west and middle Central Iran, the Upper Devonian and Carboniferous sequences were eroded. Permian deposits overlie Lower and Middle Devonian strata in most localities of Central Iran. There is an abrupt change in the type of sedimentation in the Mesozoic, with Middle Triassic limestones overlain by thick sandy sediments and argillaceous Upper Triassic rocks (Nayband Formation). The Liassic Shemshak Group contains coal and cyclic sediments revealing that the Cimmerian orogeny resulted in a change of facies probably in a nearshore zone or near the edge of a lake, as the overlying Jurassic sequence contains sandstone beds with ripple marks. Following the late Cimmerian orogeny, the Early Cretaceous sea advanced onto the small continent of Central Iran. The transgression in the Soh area began in the late Barremian and continued to the early Albian. A sequence of thick sediments eroded 
by this uplift included several lithologies such as red conglomerate, sandstones and limestones. Orbitolina gray limestones with marl intercalations are late Aptian in age (Figures 1.2, 2). Shales with intercalations of limestone contain ammonites and green to gray marly limestone with nodules that include the crustaceans here reported: small turritellid gastropods and nuculid bivalves. Trigonia and ammonites can be found throughout the unit, along with Tetragonites sp., Beudanticeras sp., B. beudanti (Brongniart, 1822), Douvilleiceras sp., Puzosia sp., which indicate an Albian (Beudanticeras Shale) age for this sequence (SeyedEmami et al., 1971; Kalantari, 1981; Amirshahkarami, 1998; Amirshahkarami and Vaziri-Moghadam, 2000). Thick, micritic Turonian limestones overlie the crustacean beds (Figure 1.2). The youngest sequence (Eocene and OligoMiocene, Qom Formation) can be observed anywhere in the plain (Figure 1.4). An angular unconformity is present between the Pliocene and the Pleistocene (clastic and travertine), and different ages below this sequence can be traced throughout the area. This angular unconformity is a result of the final alpine orogenic phase.

The studied section (Figure 2 ) is located near the village of Soh (70 km northwest of Isfahan) and is accessible by a $35 \mathrm{~km}$ unpaved road off the Isfahan - Tehran highway. The section is situated on the right side of a seasonal river valley. Coordinates for the fossil locality are: N $33^{\circ} 29^{\prime} 40^{\prime \prime}$, E $51^{\circ} 33^{\prime} 10^{\prime \prime}$. Structurally, the locality belongs to the Central Iran microplate, which is restricted by the NW-SE SanandajSirjan metamorphic belt to the West, and by the Great Kavir fault to the East.

Specimens are deposited in the Department of Geology, Faculty of Science, University of Isfahan, 81746, Iran, under acronym EUIC.
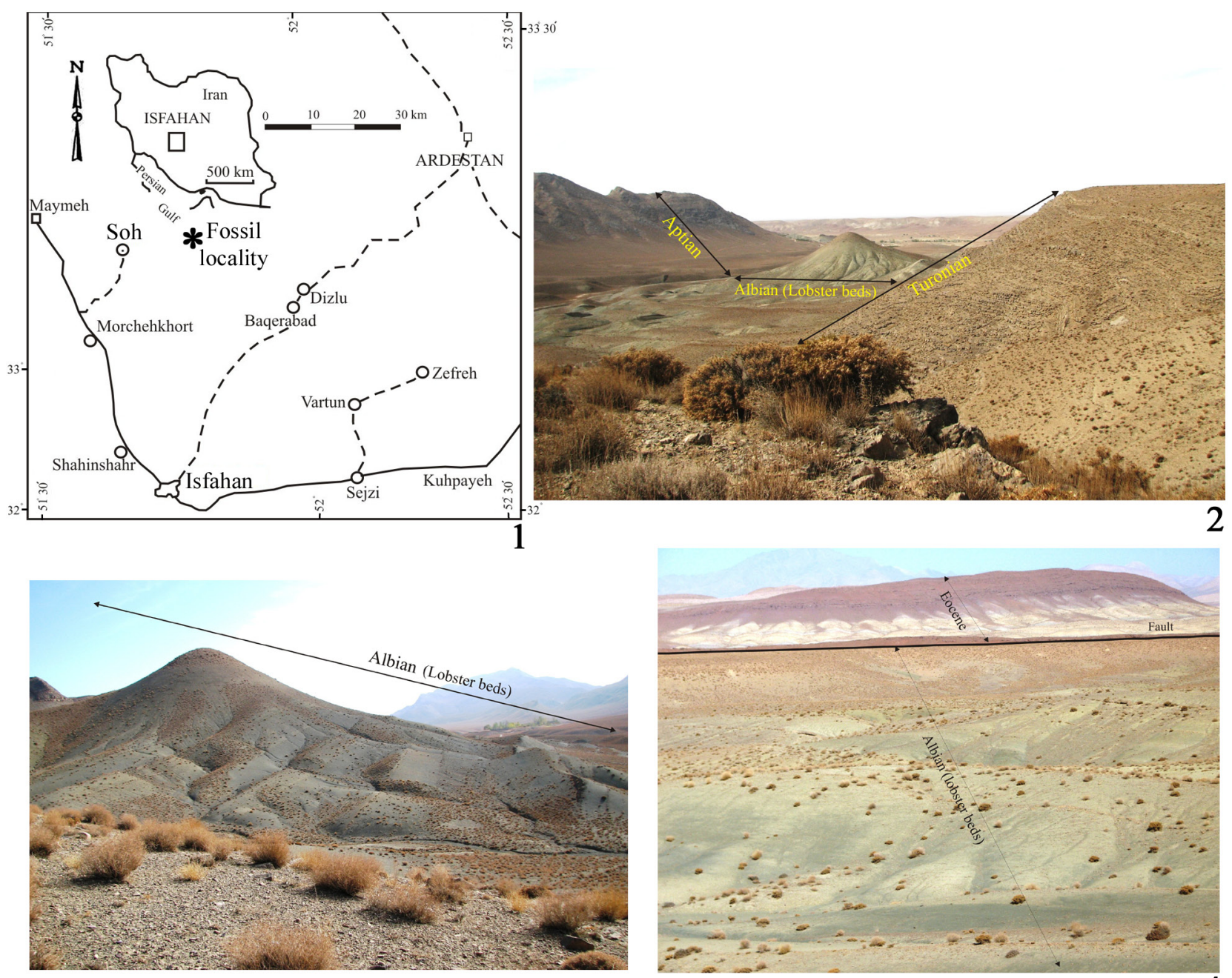

3

Figure 1. 1. Location map of study area with position of locality marked by asterisk. 2. Aptian-Turonian sequence in study area with position of Albian outcrop. 3. Detail of Albian outcrop indicating distribution of fossiliferous beds. 4. View from fossiliferous outcrop, including fault and contact with Eocene sediments. 


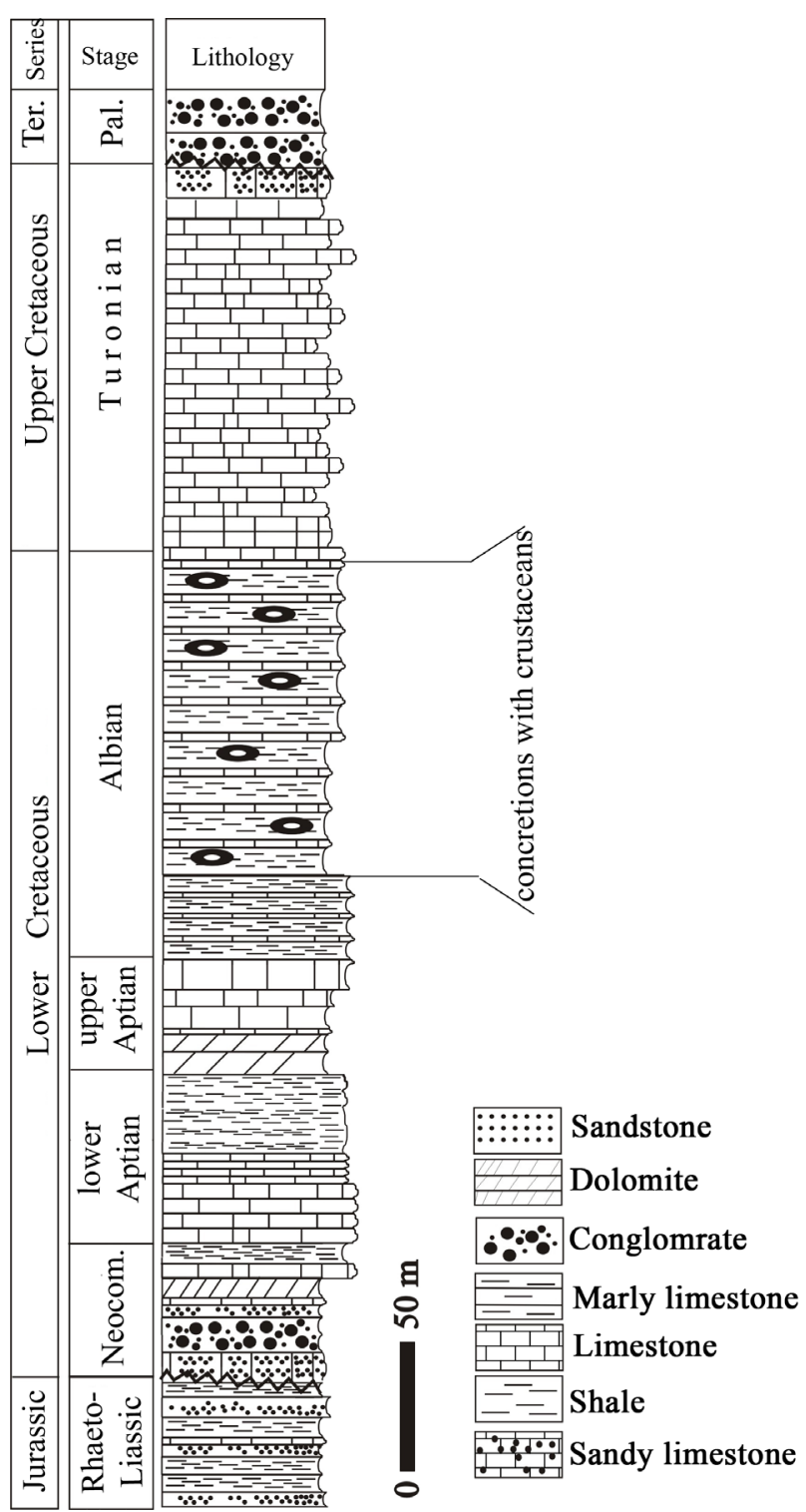

Figure 2. Stratigraphic section of study area, including position of fossiliferous beds.

\section{Systematic paleontology}

Order Decapoda Latreille, 1802

Suborder Pleocyemata Burkenroad, 1963

Infraorder Glypheidea Winckler, 1882

Superfamily Glypheoidea Winckler, 1882

Family Mecochiridae Van Straelen, 1924

Genus Huhatanka Feldmann and West, 1978
Type species. Squilla? kiowana Scott, 1970, by original designation.

Huhatanka iranica new species

Figure 3.1-3.4

Diagnosis. Small mecochirid, cephalothorax elongate, longer than high; posterior margin rimmed, curved; surface uniformly granulate; rostrum triangular, short; relatively weak median carina with fine tubercles extending from posterior portion of rostrum to cervical groove; a pair of parallel carinae extend from lateral sides of rostrum to cervical groove; antennal region one-third carapace length, with three longitudinal ridges; cervical groove deep; oblique weak ridge extends from dorsal portion of carapace on lower portion of cervical groove; granules become finer on posterolateral side of carapace; first pleonite covered by granules; first pereiopods slightly longer than reminder of pereiopods.

Description. Mecochirid of small size; carapace elongate, maximum height two thirds of maximum length, posterior margin rounded, rimmed, surface covered by relatively uniform tubercles; rostrum acute, triangular, bordered by finely granulate ridges that extend posteriorly to cervical groove; weaker median ridge also extends from tip of rostrum to cervical groove; antennal region one-third the carapace length, with three granulate longitudinal ridges, middle and lower ridges stronger; cervical groove deep, inclined toward anterolateral margin; oblique weak ridge extends from dorsal portion of carapace to lower portion of cervical groove; granules become finer on posterolateral side of carapace, first and second pleonites of similar size and shape; surface covered by granules; first pereiopod long, pereiopods 2 to 5 of similar size and length.

Etymology. Species name is dedicated to the Islamic Republic of Iran.

Types. Holotype EUIC 3757; paratypes EUIC 3758 to EUIC 3761.

Measurements (in mm). Holotype, EUIC 3757, cephalothorax length $=17.8$, width $=11.3$; paratypes, EUIC 3758 , cephalothorax length $=18.1$, height $=8.9$; EUIC 3759 , cephalothorax length $=18.4$, height $=12.1$; EUIC 3760 , cephalothorax length $=18.2$.

Discussion. The new species from Iran differs from Huhatanka kiowana (Scott, 1970) from the Albian of Kansas in having a more granulose carapace surface. The two abdominal segments preserved in the holotype of H. iranica new species are similar to the ones present in specimen KSU 3771 of the American species (Feldmann and West, 1978, pl. 1, fig.6). Dorsal carinae on anterior portion of carapace are also very similar in both species. 

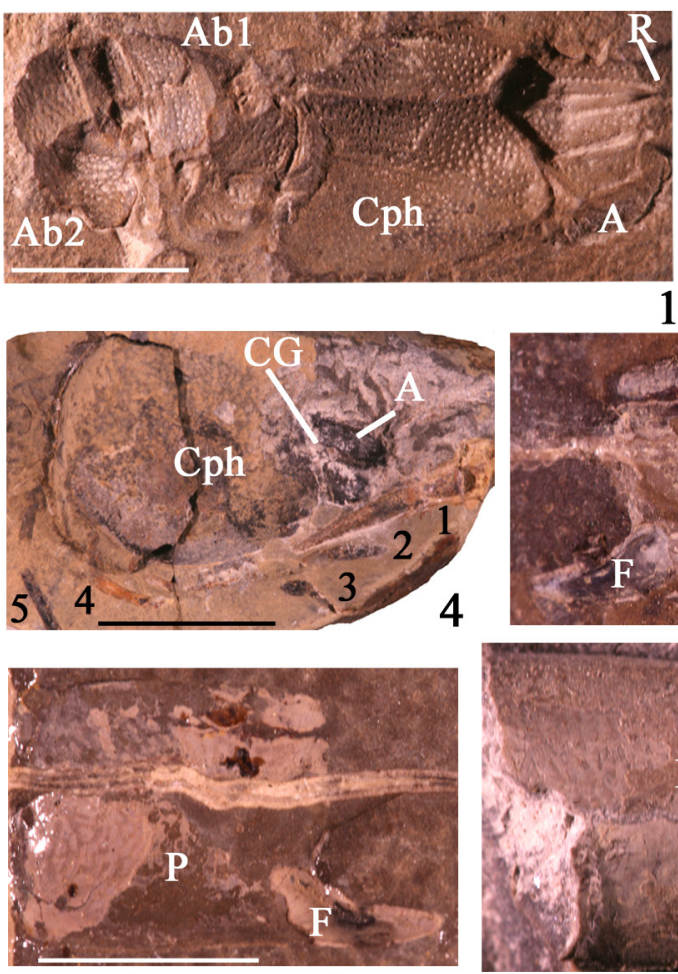

7
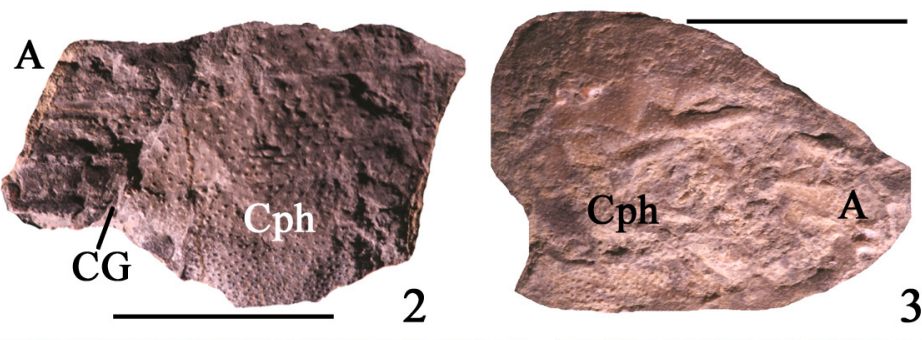

3
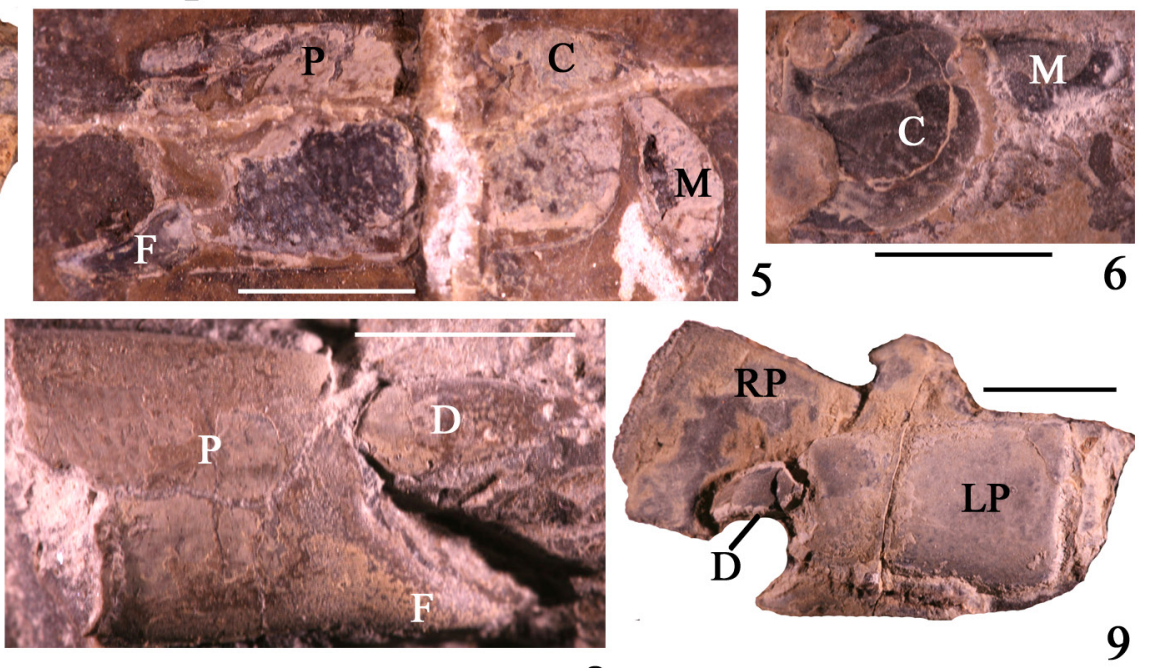

8

Figure 3. 1-4. Huhatanka iranica new species. 1, Holotype, EUIC 3757, dorsal view of cephalothorax and first abdominal segments; 2, Paratype, EUIC 3758, left view of cephalothorax; 3, Paratype, EUIC 3760, dorsal view of cephalothorax; 4, Paratype, EUIC 3759, right view of cephalothorax and pereiopods 1 to 5. 5-9. Callianassa sensu lato. 5, Hypotype, EUIC 3762, outer view of left cheliped; 6, Hypotype, EUIC 3763, merus and carpus of left cheliped; 7 , Hypotype, EUIC 3764, outer view of right palm; 8, Hypotype, EUIC 3765, outer view of right chela; 9, Hypotype, EUIC 3766, outer view of left chela and part of right manus. Reference of abbreviations: $\mathrm{A}=$ Antennal region, $\mathrm{Ab}=$ abdominal somite, $\mathrm{C}=$ carpus, $\mathrm{CG}=$ cervical groove, $\mathrm{Cph}=$ cephalothorax, $\mathrm{D}=$ dactyus, $\mathrm{F}=$ fixed finger, $\mathrm{LP}=$ left palm, $\mathrm{M}=$ merus, $\mathrm{P}=$ palm, $\mathrm{R}=$ rostrum, $\mathrm{RP}=$ right palm, $1-5=$ first to fifth pereiopods. Scale bars $=10 \mathrm{~mm}$.

Specimens from Iran are preserved in concretions, and some show deformation by dorso-ventral crushing (Figure 3.3). However, the ornament and general morphology of carapace is appropriate to suggest erection of a new species. Absence of a branchiocardiac groove and a wide gastric region distinguish Huhatanka from the recently erected Jurassic mecochirid genus Jabaloya Garassino, Artal, and Pasini, 2009, which is also larger. Presence of Huhatanka in upper Albian sediments of Iran suggests a wide distribution for the genus in the Tethyan Realm.

Infraorder Axiidea de Saint-Laurent, 1979

Family Callianassidae Dana, 1852

\section{Genus Callianassa sensu lato}

Figure 3.5-3.9

Description. Right cheliped one-third larger than left cheliped; palm of right cheliped subrectangular, highest near junction with carpus, smooth; dactylus triangular, one-third the length of palm and its width one-fifth the maximum palm height. Merus of left cheliped subovate, narrower at junction with carpus; carpus subrectangular, twice as high as long, posterior margin curved; palm subrectangular elongate, one-third longer than high; fixed finger triangular, half the length of palm and one-fourth its height.

Types. Hypotypes EUIC 3762 to EUIC 3766.

Measurements (in mm). Hypotypes EUIC 3762 left cheliped (merus + carpus + palm) length $=36.2$, height $=10.3$; EUIC 3763 left chela (merus + carpus) length $=18.5$, height $=9.8$; EUIC 3764 right palm length $=16.4$, height $=9.6$; EUIC 3765 right palm length $=22.1$, height $=12.2$; EUIC 3766 left palm length $=19.4$, height $=11.5$.

Discussion. Yazdi et al. (2009) reported Callianassoidea palm remains from the Albian of Kolah Qazi sectionBeudanticeras shale, Central Iran. It is possible that these callianassoid remains are similar to the ones here reported, but more complete and better preserved material is needed in order to allow a detailed identification. 


\section{Acknowledgments}

This study was completed at the University of Isfahan and supported by the Office of Graduate Studies, and the authors are grateful to the office for their support; we also want to thank Mrs. Rahmati, Bsc student, for the first collection samples and the Instituto de Geología, UNAM for their support in field trips and sampling North of Isfahan, Central Iran. Valuable comments to the original manuscript were offered by Rodney M. Feldmann (Kent State University). Our sincere gratitude is given to Ron Blakely (Northern Arizona University) for his permission to use a paleogeographic map.

\section{References}

Adhamian, A., 2003, Middle Devonian (Givetian) conodonts Biostratigraphy in the Soh area, north of Esfahan: Courier Forschungsinstitut Senckenberg, 295, 183-193.

Amirshahkarami, M., 1998, Biostratigraphy and Palaeobiogeography of Cretaceous (Albian- Torunian) in Kolah-Qazi area (South Southeast of Isfahan): Isfahan, Iran, University of Isfahan, M. Sc. Thesis, $139 \mathrm{p}$ (in Persian).

Amirshahkarami, M., Vaziri-Moghadam, H., 2000, Biostratigraphy of Inoceramus Limestone in Kolah-Qazi area (abstract), in 4th Symposium of the Geological Survey of Iran: Tabriz, Iran, 89-9 (in Persian).

Brongniart, A., 1822, Sur quelques terrains de Craie hors du Bassin de Paris, in Cuvier, G., Brongniart, A. (eds.) Description geologique des environs de Paris: Paris, Dufour et D'Ocagne, 80-101.

Burkenroad, M.D., 1963, The evolution of the Eucarida (Crustacea, Eumalacostraca), in relation to the fossil record: Tulane Studies in Geology, 2, 3-17.

Dana, J.D., 1852, Conspectus Crustaceorum, Conspectus of the Crustacea of the Exploring Expedition under Capt. Wilkes, U.S.N. Macroura: Proceedings of the Academy of Natural Sciences of Philadelphia, 6, 10-28.

Feldmann, R.M., West, R.R., 1978, Huhatanka, a new genus of lobster (Decapoda: Mecochiridae) from the Kiowa Formation (Cretaceous: Albian) of Kansas: Journal of Paleontology, 52, 1219-1226.

Feldmann, R.M., Kolahdouz, A., Biranvand, B., Schweigert, G., 2007, A new family, genus and species of lobster (Decapoda: Achelata) from the Gadvan Formation (Early Cretaceous) of Iran: Journal of Paleontology, 81, 405-407.
Garassino, A., Artal, P., Pasini, G., 2009, Jabaloya aragonensis n. gen., n. sp. (Crustacea, Decapoda, Mecochiridae) and Cedrillosia jurassica n. gen., n. sp. (Crustacea, Decapoda, Glypheidae) from the Upper Jurassic of Teruel Province (Aragón, Spain): Atti della Societá Italiana di Scienze Naturale e del Museo Civico di Storia Naturale di Milano, 150, 197-206.

Kalantari, A., 1981, Iranian fossils: Theran, Iran, Ministry of oil, National Iranian Oil Company, Geological laboratories publication 9, $216 \mathrm{p}$.

Latreille, P. A., 1802, Histoire naturelle, générale et particulière des Crustacés et des Insectes. Ouvrage faisant suite à l'histoire naturelle générale et particulière, composée par Leclerc de Buffon, et rédigée par C.S. Sonnini, membre de plusieurs sociétés savantes, Vol. 3: Paris, F. DuFart, 467 p.

McCobb, L.M.E., Hairapetian, V., 2009, A new lobster Paraclytia valashtensis (Crustacea, Decapoda, Nephropidae) from the Late Cretaceous of the central Alborz Range, Iran: Paläontologische Zeitschrift ,83, 419-430.

Rahmati, S., 2009, Biostratigraphy of Late Paleozoic in Soh and Abadeh area: Isfahan, Iran, University of Isfahan, M. Sc. Thesis, 152 p.

Saint-Laurent, M. de, 1979, Vers une nouvelle classification des Crustacés Décapodes Reptantia: Bulletin de l'Office National des Pêches, République Tunisienne, 3, 15-31.

Scott, R.W., 1970, Paleoecology and paleontology of the Lower Cretaceous Kiowa Formation, Kansas: Kansas, U.S.A., The University of Kansas Paleontological Contributions 52, $94 \mathrm{p}$.

Seyed-Emami, K., Brants, A., Bozorgnia, F., 1971, Stratigraphy of the Cretaceous rocks southeast of Esfahan: Theran, Iran, Geological Survey of Iran Report 20, 5-27.

Van Straelen, V., 1924, Contribution à l'étude des crustacés décapodes de la Période Jurassique: Brussels, Mémoires de l'Académie Royale de Belgique, Classe des Sciences, series 2, $462 \mathrm{p}$.

Winckler, T.C., 1882, Carcinological investigation on the genera Pemphix, Glyphea and Araeosternus: Annals and Magazine of Natural History, series 5, 10, 133-149, 306-317.

Yazdi, M., Bahrami, A., Vega, F.J., 2009, Albian decapod Crustacea from Southeast Isfahan, Central Iran-Kolah-Qazi area: Bulletin of the Mizunami Fossil Museum, 35, 71-77.

Manuscript received: January 10, 2010.

Corrected manuscript received: January 20, 2010.

Manuscript accepted: January 25, 2010. 